\title{
Hubungan Merokok dengan Kadar Hemoglobin dan Trombosit pada Perokok Dewasa
}

\author{
${ }^{1}$ Devina V. Wibowo \\ ${ }^{2}$ Damajanty H. C. Pangemanan \\ ${ }^{2}$ Hedison Polii
}
${ }^{1}$ Program Studi Pendidikan Dokter Fakultas Kedokteran Universitas Sam Ratulangi Manado
${ }^{2}$ Bagian Fisiologi Fakultas Kedokteran Universitas Sam Ratulangi
Email: devina.wibowo@yahoo.com

\begin{abstract}
Smoking is one of the leading causes of death world wide. that cause death. The World Health Organization (WHO) shows that 6 millions of people died as active smokers and 890.000 as passive smokers. Several studies suggest that smoking can influence blood components, such as erythrocytes, leukocytes, and platelets. This study was aimed to determine the correlation between smoking to hemoglobin and platelet levels in adult smokers. This was an analytical descriptive study with a cross sectional design that was conducted on 30 students of Mechanical Engineering, Faculty of Engineering, Sam Ratulangi University Manado. Data were analyzed with the One Way Anova test on hemoglobin levels and the Kruskall-Walis test on thrombocyte levels. The results showed that of the 30 respondents, 21 (70\%) had normal hemoglobin levels and $9(30 \%)$ had high hemoglobin levels. The One Way Anova test obtained a $P$ value of 0.634 . All respondents $(100 \%)$ had normal platelet counts.The Kruskall-Walis test obtained a $P$ value of 0.471 . Conclusion: There was no significant relationship between smoking with hemoglobin and platelet levels.
\end{abstract}

Keywords: smoking, hemoglobin level, platelet level.

\begin{abstract}
Abstrak: Merokok merupakan salah satu penyebab masalah kesehatan terbanyak di dunia yang menyebabkan kematian. World Health Organization (WHO) menunjukkan bahwa 6 juta orang meninggal sebagai perokok aktif dan 890 ribu orang meninggal sebagai perokok pasif. Beberapa penelitian menyatakan bahwa merokok dapat memengaruhi komponen - komponen darah, misalnya eritrosit, leukosit dan trombosit. Penelitian ini bertujuan untuk mengetahui hubungan merokok dengan kadar hemoglobin dan trombosit pada perokok dewasa. Jenis penelitian ialah deskriptif analitik dengan desain potong lintang yang dilakukan pada 30 mahasiswa Jurusan Teknik Mesin Fakultas Teknik Universitas Sam Ratulangi Manado. Uji statistik menggunakan One Way Anova pada kadar hemoglobin dan uji Kruskall-Walis pada kadar trombosit. Responden terbanyak memiliki kadar hemoglobin normal yaitu 21 orang (70\%) dan kadar hemoglobin tinggi sebanyak 9 orang (30\%). Hasil uji One Way Anova mendapatkan nilai $P=0,634$. Seluruh responden $(100 \%)$ memiliki kadar trombosit normal. Hasil uji Kruskall-Walis mendapatkan nilai $P=0,471$. Simpulan: Tidak terdapat hubungan bermakna antara merokok dengan kadar hemoglobin dan trombosit.
\end{abstract}

Kata Kunci : merokok, kadar hemoglobin, kadar trombosit

Menurut data Riset Kesehatan Dasar (Riskesdas) tahun 2013, rerata persentase perokok di Indonesia ialah 29,3\%. Persentase perokok terbanyak di Provinsi Kepulauan Riau (27,2\%), kemudian
Provinsi Bengkulu dan Jawa Barat $(27,1 \%)$, diikuti Provinsi Gorontalo dan Nusa Tenggara Barat (26,8\%). Provinsi Sulawesi Utara memiliki persentase perokok sebesar $24,6 \%^{1}$ dengan kabupaten/kota. Persentase 
perokok terbanyak di Sulawesi Utara ialah Kabupaten Bolaang Mongondow (30\%), Kabupaten Minahasa Selatan (25,6\%), dan Kota Tomohon(25\%). Kota Manado memiliki persentase perokok sebanyak $23,6 \% .^{2}$

Asap rokok mengandung sekitar 4000 senyawa kimia seperti karbon monoksida, karbon dioksida, fenol, amonia, formaldehid, piren, nitrosamin, nikotin, dan tar yang sangat berbahaya bagi tubuh manusia. ${ }^{3}$ Asap rokok juga terdiri dari berbagai oksidan dan radikal bebas yang bisa merusak lipid, protein, deoxyribonucleic acid (DNA), karbohidrat serta berbagai biomolekul lainnya. ${ }^{4}$

Merokok merupakan salah satu faktor resiko dari berbagai penyakit jantung, hipertensi, inflamasi, stroke, kelainan pembekuan darah, dan juga penyakit pernafasan. Merokok juga mempercepat patogenesis dari berbagai penyakit keganasan, misalnya keganasan paru, pankreas, payudara, hati, dan ginjal. ${ }^{5}$ Dalam penelitian beberapa tahun terakhir, dikemukakan bahwa merokok juga dapat memengaruhi komponen-komponen darah. Misalnya,pengaruh rokok pada jumlah sel darah putih (leukosit) yang menunjukkan bahwa terdapat peningkatan sel darah putih pada perokok daripada bukan perokok. ${ }^{6}$ Merokok juga diduga dapat berpengaruh pada komponen darah lainnya, misalnya eritrosit, trombosit, hemoglobin, dan sebagainya. $^{5}$

Hemoglobin adalah suatu protein tetrametrik dalam eritrosit yang berikatan dengan oksigen serta bertugas dalam melepaskan oksigen tersebut ke dalam jaringan. Selain itu, hemoglobin juga nantinya akan berikatan dengan karbon dioksida untuk mengembalikannya ke paru. ${ }^{7}$ Karbon monoksida yang terkandung dalam rokok memiliki afinitas yang besar terhadap hemoglobin, sehingga memudahkan keduanya untuk saling berikatan membentuk karboksihemoglobin, suatu bentuk inaktif dari hemoglobin. Hal ini mengakibatkan hemoglobin tidak dapat mengikat oksigen untuk dilepaskan ke berbagai jaringan sehingga menimbulkan terjadinya hipoksia jaringan. Tubuh manusia akan berusaha mengkompensasi penurunan kadar oksigen dengan cara meningkatkan kadar hemoglobin. ${ }^{8}$

Merokok secara aktif maupun pasif juga diketahui memiliki pengaruh terhadap trombosit. Seseorang yang sudah lama terpapar asap rokok mempunyai potensi terjadi peningkatan agregasi trombosit dan ekskresi metabolit tromboksan. ${ }^{9}$ Pada penelitian Butkiewicz et al. ${ }^{9}$ didapatkan peningkatan jumlah trombosit pada perokok dibandingkan dengan yang tidak merokok, meskipun secara statistik hasilnya tidak bermakna. Penelitian Swansaksri et al. ${ }^{10}$ menunjukkan hasil yang berbeda yaitu tidak terdapat perbedaan jumlah trombosit yang bermakna antara perokok dan bukan perokok.

Berdasarkan hal di atas, maka perlu diteliti hubungan merokok dengan kadar hemoglobin dan kadar trombosit pada perokok dewasa.

\section{METODE PENELITIAN}

Jenis penelitian ini ialah deskriptf analitik dengan desain potong lintang. Penelitian ini dilaksanakan pada bulan September sampai Desember 2017 dan bertempat di Fakultas Teknik Universitas Sam Ratulangi Manado dan Laboratorium Klinik. Sampel diambil dengan menggunakan teknik purposive sampling dengan jumlah responden sebanyak 30 orang yang memenuhi kriteria inklusi dan eksklusi.

Data penggunaan rokok oleh responden diketahui melalui kuesioner yang diisi oleh responden yang sebelumnya telah menyatakan bersedia dan menyatakannya dalam lembaran informed consent. Pemeriksaan kadar hemoglobin dan trombosit diambil melalui darah vena oleh petugas laboratorium dan sampel darah diperiksa di Laboratorium Klinik Prokita dengan alat Micros 60 ABX. Data diolah menggunakan program SPSS 16 dan Microsoft Office Word 2007.

\section{HASIL PENELITIAN}

Berdasarkan usia, responden paling banyak berusia 18 dan 19 tahun dengan 
jumlah 6 orang (20\%). Responden berusia 24 tahun merupakan usia tertua yang mengikuti penelitian ini sebanyak 2 orang $(6,67 \%)$ (Tabel 1).

Tabel 1. Karakteristik dasar responden berdasarkan usia

\begin{tabular}{ccc}
\hline $\begin{array}{c}\text { Usia } \\
\text { tahun) }\end{array}$ & $\begin{array}{c}\text { Frekuensi } \\
(\mathbf{n})\end{array}$ & $\begin{array}{c}\text { Persentase } \\
(\boldsymbol{\%})\end{array}$ \\
\hline 18 & 6 & 20 \\
19 & 6 & 20 \\
20 & 4 & 13,33 \\
21 & 4 & 13,33 \\
22 & 5 & 16,67 \\
23 & 3 & 10 \\
24 & 2 & 6,67 \\
Total & 30 & 100 \\
\hline
\end{tabular}

Tabel 2 memperlihatkan bahwa responden terbanyak dengan parameter lamanya merokok ialah yang merokok selama 1-5 tahun sebanyak 18 orang (60\%). Jumlah rokok terbanyak yang dikonsumsi responden ialah 10-19 batang per hari dengan jumlah responden 19 orang $(63,3 \%)$. Responden terbanyak dengan parameter usia pertama merokok ialah yang merokok pada usia 11-15 tahun sebanyak 14 orang $(46,7 \%)$. Responden dengan klasifikasi terbanyak ialah perokok sedang sebanyak 19 orang $(63,3 \%)$.

Tabel 2. Karakteristik responden berdasarkan penggunaan rokok

\begin{tabular}{lccc}
\hline \multicolumn{2}{c}{ Parameter } & $\begin{array}{c}\text { Frekuensi } \\
(\mathbf{n})\end{array}$ & $\begin{array}{c}\text { Persentase } \\
(\%)\end{array}$ \\
\hline Lama & $1-5$ & 18 & 60 \\
merokok & $6-10$ & 11 & 36,7 \\
(tahun) & $\geq 11$ & 1 & 3,3 \\
Usia & $6-10$ & 3 & 10 \\
pertama & $11-15$ & 14 & 46,7 \\
merokok & $\geq 16$ & 13 & 43,3 \\
(tahun) & Ringan & 7 & 23,3 \\
Klasifikasi & Sedang & 19 & 63,3 \\
merokok & Berat & 4 & 13,3 \\
(WHO) & & &
\end{tabular}

Berdasarkan Tabel 3, responden terbanyak memiliki kadar hemoglobin normal yaitu sebanyak 21 orang $(70 \%)$ dengan rerata kadar hemoglobin 16,02 $\mathrm{g} / \mathrm{dL}$. Responden dengan kadar hemoglobin meningkat sebanyak 9 orang $(30 \%)$ dengan rerata kadar hemoglobin $17,89 \mathrm{~g} / \mathrm{dL}$.

Semua responden memiliki kadar trombosit normal yaitu 30 orang (100\%) dengan rata-rata kadar trombosit 266,87 . $10^{3} / \mathrm{mm}^{3}$ dan tidak ada responden yang memiliki kadar trombosit rendah atau tinggi (Tabel 4).

Tabel 3. Karakteristik responden berdasarkan kadar hemoglobin $(\mathrm{Hb})$

\begin{tabular}{ccccc}
\hline $\begin{array}{c}\text { Klasifikasi kadar } \\
\text { Hb }\end{array}$ & $\begin{array}{c}\text { Nilai rujukan } \\
(\mathbf{g} / \mathbf{d L})\end{array}$ & $\begin{array}{c}\text { Frekuensi } \\
(\mathbf{n})\end{array}$ & $\begin{array}{c}\text { Mean Hb } \\
(\mathbf{g} / \mathbf{d L})\end{array}$ & $\begin{array}{c}\text { Persentase } \\
(\mathbf{\%})\end{array}$ \\
\hline Rendah & $<11,7$ & 0 & 0 & 0 \\
Normal & $11,7-17,3$ & 21 & 16,02 & 70 \\
Tinggi & $>17,3$ & 9 & 17,89 & 30 \\
\hline
\end{tabular}

Tabel 4. Karakteristik responden berdasarkan kadar trombosit (Plt)

\begin{tabular}{ccccc}
\hline $\begin{array}{c}\text { Klasifikasi } \\
\text { kadar Plt }\end{array}$ & $\begin{array}{c}\text { Nilai rujukan } \\
\left(\mathbf{. 1 0} / \mathbf{m m}^{\mathbf{3}}\right)\end{array}$ & $\begin{array}{c}\text { Frekuensi } \\
(\mathbf{n})\end{array}$ & $\begin{array}{c}\text { Mean Plt } \\
\left(\mathbf{( 1 0}^{\mathbf{3}} \mathbf{\mathbf { m m } ^ { \mathbf { 3 } } )}\right.\end{array}$ & Persentase (\%) \\
\hline Rendah & $<150$ & 0 & 0 & 0 \\
Normal & $150-450$ & 30 & 266,87 & 100 \\
Tinggi & $>450$ & 0 & 0 & 0 \\
\hline
\end{tabular}


Analisis data hubungan merokok dengan kadar hemoglobin $(\mathrm{Hb})$ mendapatkan nilai $P=0,634 \quad(P>0,05)$ yang menunjukkan tidak terdapat hubungan bermakna antara merokok (ringan, sedang, berat) dengan kadar hemoglobin.

Analisis data hubungan merokok dengan kadar trombosit mendapatkan nilai $P=0,471 \quad(P>0,05)$ yang menunjukkan tidak terdapat hubungan bermakna antara merokok (ringan, sedang, berat) dengan kadar trombosit.

\section{BAHASAN}

Pada penelitian ini, responden dengan kadar hemoglobin normal mendapatkan kadar rerata hemoglobin 16,02 $\mathrm{g} / \mathrm{dL}$ sedangkan responden dengan kadar hemoglobin tinggi memiliki kadar rerata hemoglobin 17,89 g/dL. Hasil rerata kadar hemoglobin responden dalam batasan normal.

Menurut penelitian yang dilakukan oleh Leifert, ${ }^{8}$ peningkatan kadar hemoglobin pada perokok yang disebabkan oleh paparan terhadap karbon monoksida (CO) yang merupakan salah satu komponen rokok. Penelitian serupa yang dilakukan oleh Amelia et al. ${ }^{11}$ terhadap 65 orang pendonor darah di Palang Merah Indonesia cabang Padang, menemukan bahwa tidak terdapat hubungan bermakna antara derajat merokok dengan hemoglobin. Penelitian oleh Susiyati ${ }^{12}$ mengenai hubungan kebiasaan merokok dan kadar hemoglobin dengan kesegaran jasmani yang dilakukan pada siswa Sekolah Menengah Kejuruan (SMK) juga menunjukkan tidak adanya hubungan bermkna antara lama merokok dengan jumlah rokok yang dikonsumsi perhari dengan kadar hemoglobin.

Hasil penelitian ini tidak selaras dengan yang dilakukan oleh Shah et al. ${ }^{13}$ yang mendapatkan kadar hemoglobin pada perokok lebih tinggi jika dibandingkan dengan non perokok. Pada penelitian yang dilakukan oleh Bashir et al. ${ }^{14}$ dilaporkan juga peningkatan kadar hemoglobin yang berkorelasi dengan peningkatan ukuran eritrosit pada perokok jika dibandingkan dengan bukan perokok.
Terdapat beberapa faktor yang memengaruhi kadar hemoglobin pada tiap individu, yakni : usia, jenis kelamin, asupan gizi, aktivitas fisik, ketinggian daerah tempat tinggal, kebiasaan lamanya menghisap rokok, obat-obatan yang dikonsumsi, serta alat dan metode tes yang digunakan. Peneliti tidak meninjau lebih lanjut mengenai beberapa faktor yang dapat memengaruhi kadar hemoglobin seperti asupan gizi, derajat aktivitas fisik, ketinggian daerah tempat tinggal, yang dapat berdampak pada nilai dari kadar hemoglobin responden.

Hasil kuesioner menunjukkan beberapa responden yang rutin mengonsumi alkohol bersamaan dengan rokok. Alkohol diketahui memberi dampak pada parameter hematologi; salah satunya ialah penekanan proses hematopoesis atau produksi sel darah. Namun toksisitas alkohol bergantung pada dosis penggunaan, maka gangguan hematopoiesis cenderung terjadi pada orang yang mengonsumsi alkohol kronik. ${ }^{15}$ Peneliti juga tidak meneliti lebih lanjut mengenai pengaruh alkohol pada kadar hemoglobin perokok, sehingga hal ini dapat berdampk pada nilai dari kadar hemoglobin responden.

Penelitian ini menggunakan data primer berupa kuesioner untuk mendapatkan data konsumsi rokok dan pemeriksaan darah vena untuk melihat kadar hemoglobin. Data yang didapatkan dari kuesioner juga tergantung dari kejujuran responden serta pemahaman responden terhadap pertanyaan yang diajukan. Selain itu terbatasnya jumlah responden yang memenuhi kriteria inklusi dan eksklusi juga mungkin berpengaruh terhadap hasil penelitian.

Hasil penelitian ini menunjukkan bahwa tidak terdapat hubungan bermakna antara merokok dengan kadar trombosit. Hasil penelitian ini serupa dengan yang dikemukakan oleh Suwansaksri et al. ${ }^{10}$ yang menunjukkan bahwa tidak terdapat perbedaan bermakna dari parameter trombosit (kadar trombosit, Mean Platelet Volume, Platelet Distribution Width dan Platelecrit) antara perokok dan non- 
perokok. Penelitian lain yang dilakukan oleh Blann et al. $^{16}$ menunjukkan hasil selaras yaitu tidak terdapat hubungan bermkna antara merokok dengan kadar trombosit pada perokok namun didapatkan peningkatan bermakna parameter trombosit yang lain, yakni platelet surface P-selectin yang diduga lebih sensitif terhadap paparan asap rokok.

Beberapa penelitian lain menunjukkan hasil yang berbeda mengenai hubungan merokok dengan kadar trombosit. Penelitian yang dilakukan oleh Nagvekar et al. ${ }^{17}$ pada hewan coba tikus yang diberikan paparan asap rokok selama 12 minggu memberikan hasil peningkatan trombosit jika dibandingkan dengan kelompok tikus kontrol.

Namun hasil yang berbeda ditemukan pada penelitian serupa. Penelitian yang dilakukan oleh Varol et al. ${ }^{18}$ menunjukkan hasil yang berlawanan dengan hasil penelitian sebelumnya yaitu terdapat penurunan jumlah trombosit pada perokok jika dibandingkan dengan nonperokok.

Terdapt beberapa hal yang dapat menimbulkan perbedaan hasil penelitian seperti usia, jenis kelamin, kebiasaan merokok, dan juga etnis. Peneliti tidak meninjau lebih lanjut mengenai faktorfaktor tersebut sehingga dapat mengganggu nilai dari kadar trombosit.

Konsumsi alkohol juga dapat memengaruhi kadar trombosit pada perokok. Teori mengatakan bahwa alkohol dapat menyebabkan trombositopenia. ${ }^{15}$ Limitasi penelitian ini ialah peneliti tidak meneliti lebih lanjut mengenai pengaruh alkohol terhadap kadar trombosit pada perokok sehingga hal ini dapat mengganggu nilai kadar trombosit responden.

\section{SIMPULAN}

Tidak terdapat hubungan antara merokok dengan kadar hemoglobin dan kadar trombosit.

\section{SARAN}

Perlu dilakukan penelitian lebih lanjut mengenai merokok, kadar hemoglobin dan kadar trombosit dalam jumlah sampel yang lebih besar dan cakupan yang lebih luas.

Perlu diteliti faktor kebiasaan hidup (konsumsi alkohol) dalam pengaruhnya terhadap kadar hemoglobin dan kadar trombosit pada perokok

Perlu dilakukan tes fungsi paru kepada responden untuk mengetahui efek rokok terhadap fungsi paru.

\section{UCAPAN TERIMA KASIH}

Ditujukan kepada seluruh mahasiswa Jurusan Teknik Mesin Fakultas Teknik Universitas Sam Ratulangi Manado atas partisipasinya, Laboratorium Klinik Prokita atas bantuan dan kerja samanya, serta pihak lain yang terlibat dalam penyelesaian penelitian ini.

\section{DAFTAR PUSTAKA}

1. Badan Penelitian dan Pengembangan Kesehatan Kementrian Kesehatan RI. RISKESDAS 2013. Jakarta: Badan Penelitian dan Pengembangan Kesehatan, 2013; p. 132-3.

2. Badan Penelitian dan Pengembangan Kesehatan Kementrian Kesehatan RI. Laporan Hasil RISKESDAS Provinsi SULUT Tahun 2007. Jakarta: Badan Penelitian dan Pengembangan Kesehatan, 2007; p. 121-2.

3. Tirlapur VG, Gicheru K, Charalambous BM, Evans PJ, Mir MA. Packed cell volume, haemoglobin, and oxygen saturation changes in healthy smokers and non smokers. Thorax. 1983;38(10): 785-7.

4. Carel RS, Eviatar J. Factors affecting leukocyte count in healthy adults. Prev Med 10985;14:607-19.

5. Asif M, Karim S, Umar Z, Malik A, Ismail T, Chaudhary A, et al. Effect of cigarette smoking based on hematological parameters: comparison between male smokers and non-smokers. Turk $\mathbf{J}$ Biochem. 2013;38(1):75-80

6. Islam MM, Amin MR, Begum S, Akther D, Rahman A. Total count of white blood cells in adult male smokers. J Bangladesh Soc Physiol. 2007;2:49-53.

7. Granner DK, Murray RR, Rodwell VW, editor. Biokimia Harper (27 th ed, terjemahan). Jakarta: EGC, 2009; p. 44. 
8. Leifert JA. Anemia and cigarette smoking. Int J Lab Hematol. 2008;30:177-84.

9. Butkiewicz AM, Kemona-Chetnik I, Dymicka-Piekarska V, MatowickaKarna J, Kemona H, Radziwon $\mathbf{P}$. Does smoking affect thrombocytopoiesis and platelet activation in women and men? Adv Med Sci. 2006;51:123-6.

10. Suwansaksri J, Wiwanitkit V, Soogarun S. Effect of smoking on platelet count and platelet parameters: an observation. Clin Appl Thrombosis/Hemostasis. 2004; 10(3):287-8.

11. Amelia R, Nasrul E, Basyar M. Hubungan derajat merokok berdasarkan Indeks Brinkman dengan kadar hemoglobin. Jurnal Kesehatan Andalas. 2016;5(3): 619-24.

12. Susiyati E. Hubungan kebiasaan merokok dan kadar hemoglobin dengan kesegaran jasmani siswa putra sekolah menengah kejuruan (studi di SMK Muhammadiyah 1 Surakarta) [Skripsi]. Semarang: Fakultas Kedokteran Universitas Diponegoro; 2007.

13. Shah BK, Nepal AK, Agrawal M, Sinha AK. The effects of cigarette smoking on hemoglobin levels compared between smokers and non smokers. Sunsari Technical College Journal. 2012;I(1):424.

14. Bashir BA, Gibreel MO, Abdalatif HM, Mohamed MA, Ahmed EA, Mohamed MS, et al. Impact of tobacco cigarette smoking on hematologic parameters among male subjects in Port Sudan Ahlia College, Sudan. Sch J App Med Sci. 2016;4(4A):1124-48.

15. Ballard HS. The hematological complication of Alcoholism. Alcohol Health Exp Res. 1997;21(1):42-52.

16. Blann AD, Kirkpatrick U, Devine C, Naser S, McCollum CN. The influence of acute smoking on leukocytes, platelets and th endothelium. Atherosclerosis. 1998;141: 133.

17. Nagvekar M, Abraham ME. Effect of cigarette smoking and 3.2\% ethanol alone or together on RBC and platelet counts in rats. Ind J Physiol Pharmacol. 2002; 46:367

18. Varol E, Icli A, Kocyigit S, Erdogan D, Ozaydin M, Dogan A. Effect of smoking cessation on mean platelet volume. Clin Appl Thrombosis/Hemostasis. 2013; 19(3):315-19. 